\title{
SPECIFIC CHARACTERISTICS OF OCULAR BIOMETRIC FACTORS IN GLAUCOMATOUS PATIENTS WITH PSEUDOEXFOLIATIVE SYNDROME AS MEASURED BY OPTICAL LOW-COHERENCE REFLECTOMETRY
}

\author{
Željka Janjetović ${ }^{1}$, Mladen Bušić ${ }^{2}$ Damir Bosnar ${ }^{2}$, Josip Barać ${ }^{3}$ and Ivanka Genda ${ }^{2}$ \\ ${ }^{1}$ Department of Ophthalmology and Optometry, Dr Josip Benčević General Hospital, Slavonski Brod, Croatia; \\ ${ }^{2}$ Department of Ophthalmology, Sveti Duh University Hospital, Zagreb, School of Medicine, \\ Josip Juraj Strossmayer University, Osijek, Croatia; ${ }^{3}$ Department of Ophthalmology, Osijek University \\ Hospital Center, School of Medicine, Josip Juraj Strossmayer University, Osijek, Croatia

\begin{abstract}
SUMMARY - The aim of the study was to assess biometric factor aberrations and differences among groups of eyes with cataract and pseudoexfoliative syndrome, cataract and pseudoexfoliative glaucoma, and cataract and primary open-angle glaucoma (POAG), and to determine biometric factors of the eye specific for the group of glaucomatous patients with pseudoexfoliative syndrome by use of optical low-coherence reflectometry. This retrospective study included 72 patients, and the study sample of 102 eyes was divided into the following three groups according to diagnosis: 29 eyes with pseudoexfoliative syndrome and cataract; 36 eyes with POAG and cataract; and 37 eyes with pseudoexfoliative glaucoma and cataract. Data on biometric measurements (central corneal thickness, pupillary diameter, anterior chamber depth, lens thickness, axial length, retinal thickness, astigmatism and white-to-white) obtained by use of optical low-coherence reflectometry on a Lenstar LS $900^{\circledR}$ (HaagStreit International) were collected and analyzed by thorough survey of medical documentation of patients scheduled for cataract surgery at Department of Ophthalmology, Sveti Duh University Hospital in Zagreb, Croatia. Comparative analysis of the groups yielded statistically significant differences in central corneal thickness ( $F 2 / 99=7.066 ; p=0.001)$ and lens thickness ( $F 2 / 96=5.133 ; p=0.008)$. The group of eyes diagnosed with pseudoexfoliative glaucoma and cataract had a significantly thinner cornea as compared with the other two groups and a significantly thicker lens as compared with the group of eyes with POAG and cataract. In conclusion, optical low-coherence reflectometry revealed differences in biometric factors among the three groups of eyes, with a statistically significantly thinner cornea and thicker lens in the group of glaucomatous patients with pseudoexfoliative syndrome.
\end{abstract}

Key words: Exfoliation syndrome; Optic low-coherence reflectometry; Glaucoma, open-angle; Cataract

\section{Introduction}

Pseudoexfoliative (PEX) syndrome is a generalized disorder of the extracellular matrix characterized by the production and accumulation of fibril granulated

\footnotetext{
Correspondence to: Assist. Prof. Damir Bosnar, MD, PhD, Department of Ophthalmology, Sveti Duh University Hospital, Sveti Duh 64, HR-10000 Zagreb, Croatia

E-mail: damir.bosnar@gmail.com

Received May 25, 2017, accepted July 2, 2018
}

protein (exfoliative material) in the anterior eye segment tissues and connective tissue of visceral organs ${ }^{1-4}$. $\mathrm{PEX}$ syndrome is a disorder associated with older age, found all over the world population, however, with great ethnic and geographical differences in its prevalence. The average age at its onset across the populations is $\geq 60$ years, while the average prevalence is estimated to $10 \%-20 \%$. In the eye, PEX syndrome manifests as the presence of pseudoexfoliative material deposits on the anterior lens capsule, ciliary body, zonules, 
pupillary edge, corneal endothelium, anterior vitreous, trabeculum and connective tissue in the eyeball ${ }^{4-7}$. The etiopathogenesis of the syndrome has not yet been fully clarified, but it is known to involve both genetic and non-genetic factors. Recent research supports the pathogenetic concept of PEX syndrome as a form of stress induced systemic elastosis associated with overproduction and progressive accumulation of fibrillar material in the anterior eye segment tissues and connective tissue of visceral organs (liver, lung, heart, kidney and vascular walls). Several genes have been recognized as most responsible for development of PEX syndrome, in particular lysyl oxidase-like 1 (LOXL1) gene polymorphism on chromosome $15 \mathrm{q} 24.1$ in the populations investigated, with a contribution of additional genes with relatively small effects (clustrein, contactin associated protein-like 2 (CNTNAP2), apolipoprotein E, glutathione S-transferase, adenosine, and tumor necrosis factor-alpha (TNF- $\alpha)$ ). LOXL1 polymorphism is related to the action of profibrillar transforming growth factor-beta (TGF- $\beta$ ) and tissue inhibitors of metalloproteinases (TIMPs) with consequential progressive production and accumulation of PEX material. Current concepts also confirm the effect of oxidative stress in the genesis of PEX syndrome, as well as impaired cellular self-defense, along with reduced levels of tissue antioxidants, leading to impaired matrix metabolism and inducing proinflammatory state ${ }^{8,9}$. Pathologic production and deposition of PEX material has been associated with development of intraocular complications (corneal endotheliopathy, iridopathy with reduced pupillary opening, ciliary body alterations, instability and degenerative changes of zonular apparatus, increased lens mobility, lens or intraocular graft decentration and dislocation, pigment dispersion, secondary open-angle and angle-closure glaucoma, pseudouveitis, anterior synechiae, and anterior chamber hypoxia). The condition poses an increased risk of intraoperative complications (lesions of zonular apparatus, rupture of lens capsule, loss of vitreous, prolonged time of postoperative inflammatory reaction, and postoperative elevation of intraocular pressure $)^{7,10-13}$. PEX syndrome poses a four-fold greater risk of glaucoma ${ }^{14}$. In the presence of PEX syndrome, glaucoma develops in $15 \%-20 \%$ of cases within 10 years. According to the onset mechanism, it is secondary open-angle or angle-closure glaucoma, both showing progressive course and poor therapeutic re- sponse. PEX glaucoma develops as secondary openangle glaucoma in 15\%-20\% of open-angle glaucoma cases. Accumulation of PEX material and pigment in chamber angle, as well as morphological changes in the trabecular space, Schlemm's canal, juxtacanalicular space, presence of synechiae, iridal tissue atrophy, weakness of zonular apparatus, increased lens mobility and lens forward migration, and ciliary block condition increase resistance to aqueous humor circulation and drainage, and increase intraocular pressure in the eye with PEX syndrome ${ }^{1,10}$. Modern operative techniques employed in cataract surgery and refractive surgery, and use of new-generation biometric formulas to calculate intraocular lens strength require extensive and accurate preoperative biometric ophthalmologic status in order to achieve the best possible postoperative results. Previous studies using various biometric methods attempted to explain the relationships between biometric aberrations and pathophysiological events in the eye with PEX syndrome and PEX glaucoma, and their effect on the occurrence of intra- and postoperative complications. It is well known that PEX syndrome is one of the most common causes of complications in cataract surgery, whereas the results of previous studies on biometric factor aberrations in the eye with PEX syndrome with or without glaucoma are contradictory.

Aberrations in the values of biometric factors such as lower anterior chamber depth (ACD), lower pupillary diameter (PD) and higher lens thickness (LT) point to zonular apparatus instability, presence of synechiae, forward lens migration and increased mobility of the lens or intraocular artificial lens implant $t^{13,15}$. Preoperative detection of biometric factor aberrations enables assessment of the risk of intra- and postoperative complications in cataract and glaucoma surgery, and the need of operative technique and intraocular artificial lens implant adjustment.

The aim and purpose of the present study was to determine biometric factors of the eye specific for the group of glaucomatous patients with PEX syndrome and variation in biometric factors among the study groups of eyes by use of optical low-coherence reflectometry (OLCR), and to define the role of OLCR in the diagnosis of glaucomatous patients with PEX syndrome. OLCR is a non-contact, noninvasive biometric method providing extensive biometric status by simultaneous measurement of central corneal thickness 
$(\mathrm{CCT}), \mathrm{ACD}$, corneal curvature radius ( $\mathrm{K} 1$ and $\mathrm{K} 2$ keratometry), $\mathrm{PD}$, astigmatism (AST), white-to-white corneal diameter (WTW), axial length of the eye (AL), LT and retinal thickness (RT).

\section{Patients and Methods}

The investigation was designed as a retrospective, observational study aiming to compare the results of biometric measurements performed by OLCR in different study samples. Data were collected from medical documentation on patients scheduled for cataract surgery at Department of Ophthalmology, Sveti Duh University Hospital in Zagreb, Croatia. Three groups of eyes based on the preset characteristics were established, using the inclusion/exclusion criteria: eyes with PEX syndrome and cataract; eyes with PEX glaucoma and cataract; and eyes with primary open-angle glaucoma (POAG) and cataract. Results of preoperative biometric measurements obtained by OLCR on a Lenstar LS $900{ }^{\circledR}$ (Haag-Streit International, Köniz, Switzerland) were analyzed. The study included 102 eyes of 72 patients ( 44 female and 28 male) older than 40, examined before cataract surgery. There were 29 eyes with PEX syndrome and cataract; 36 eyes with POAG and cataract; and 37 eyes with PEX glaucoma and cataract.

\section{Inclusion criteria}

- Presence of POAG and cataract

- Presence of anterior eye segment lesions typical for PEX syndrome (PEX material on pupillary margin and lens capsule) along with the presence of cataract but free from lesions typical for glaucoma

- Presence of lesions in the anterior eye segment and chamber angle typical for PEX syndrome, with medical history and signs of glaucoma and cataract

\section{Exclusion criteria}

- Patients scheduled for cataract surgery diagnosed with cataract and other pathologic or posttraumatic eye lesions during the process of preoperative biometric diagnostics, and patients diagnosed with another form of primary or secondary glaucoma in addition to cataract
Medical documentation of each patient contained the following data necessary for the study:

- medical history (data on age, sex, presence/absence of eye disease prior to cataract surgery and on previous diseases)

- ophthalmologic status (visual acuity, biomicroscopy results, intraocular pressure value measured by applanation tonometry, results of fundus examination by direct and indirect ophthalmoscopy, visual field changes described, and quantitative results of biometric measurements carried out by OLCR on a Lenstar LS $900^{\circledR}$ (HaagStreit International, Köniz, Switzerland).

Lenstar LS $900^{\circledR}$ (Haag-Streit International, Köniz, Switzerland) is an optical biometer using 820 $\mathrm{nm}$ superluminescent diode as a source of coaxial infrared rays, has a spectrum range of $20-30 \mathrm{~nm}$ and short $30-\mu \mathrm{m}$ coherence, resulting in high spatial resolution. The device provides thorough biometric status by simultaneous measurement of CCT, ACD, K1 and $\mathrm{K} 2$, PD, AST, WTW, AL, LT and RT. The method is non-contact, noninvasive, rapid, painless, and cannot be performed in case of nontransparent optical media (e.g., complete lens opacity, vitreous hemorrhage or retinal detachment).

\section{Ethics}

The use of patient medical documentation and study design were approved by Ethics Committee of Sveti Duh University Hospital, Zagreb.

\section{Statistics}

In order to get answers to the questions posed in the study, we used statistical tests to compare the mean results recorded in the three groups of eyes (eyes with PEX syndrome and cataract; eyes with PEX glaucoma and cataract; and eyes with POAG and cataract) for the study parameters (AL, ACD, K1, K2, AST, LT, CCT, RT, PD and WTW). Depending on the normal or non-normal data distribution, analysis of variance (normal data distribution) or Kruskal-Wallis test (non-normal data distribution) was performed, both intended to test the level of statistical significance when comparing more than two groups. We also analyzed differences in the measured values within particular groups according to age and sex. Depending on data distribution, we used analysis of variance (normal 
data distribution) or Kruskal-Wallis test (non-normal data distribution). Results of these tests showed whether there were age and sex differences in the mean measured values for a particular diagnosis. The level of statistical significance was set at $5 \%$.

\section{Results}

The study included 102 eyes of 72 patients (44 female and 28 male). Female predominance was higher in the PEX syndrome/cataract group (63.6\% female and $27.4 \%$ male) and POAG/cataract group (63.0\% female and $27.0 \%$ male) as compared with the PEX glaucoma/cataract group $(54.5 \%$ female and $36.5 \%$ male); however, this difference did not reach statistical significance $\left(\chi^{2}=0.486 ; \mathrm{ss}=2 ; \mathrm{p}=0.784\right)$. The mean age was $79.61 \pm 6.50$ and $79.41 \pm 5.27$ years in the PEX syndrome/cataract and PEX glaucoma/cataract groups, respectively. In the POAG/cataract group, the mean age was younger (70.81 \pm 7.80 years). Patient age differed statistically significantly according to diagnosis $(F 2 / 69=14.204 ; p<0.001)$. Statistically significant differences were recorded between the PEX syndrome/ cataract and POAG/cataract groups and between the PEX glaucoma/cataract and POAG/cataract groups (Scheffe test, $\mathrm{p}<0.001$ both) (Fig. 1). There was no age difference between patients diagnosed with PEX syndrome/cataract and those with PEX glaucoma/cataract (Scheffe test, $p=0.995$ ). Analysis of biometric status of eyes diagnosed with PEX syndrome/cataract according to age yielded significant correlation only with LT ( $r=0.564 ; \mathrm{p}=0.008)$, i.e. older patients had a statistically significantly higher LT value.

Comparison according to sex yielded a statistically significant difference in pupillometry results $(\mathrm{t}=2.474$; $s s=20 ; p=0.022$ ), i.e. women showed higher mean PD as compared with men $(\mathrm{M}=5.7 \pm 1.103 \mathrm{~mm}$ vs. $\mathrm{M}=4.6 \pm 0.855 \mathrm{~mm})$. In the POAG/cataract group, neither age nor sex difference reached statistical significance. Analysis of biometric status of the eyes diagnosed with PEX glaucoma/cataract according to age showed statistically significant correlation with LT $(\mathrm{r}=0.472 ; \mathrm{p}=0.027)$ and WTW $(\mathrm{r}=0.512 ; \mathrm{p}=0.015)$. Older patients had thicker lens and smaller corneal diameter. Testing according to sex yielded no statistically significant differences. Comparative analysis of biometric factors measured in all study groups (PEX syndrome/cataract, POAG/cataract and PEX glaucoma/

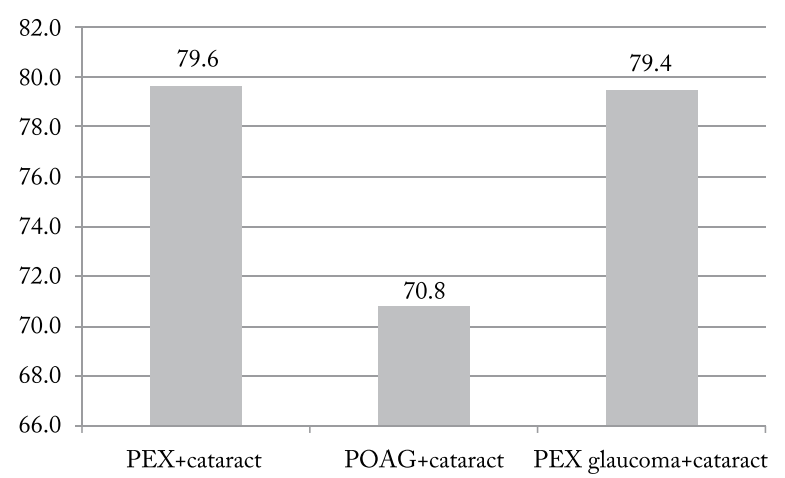

Fig. 1. Patient mean age according to diagnosis.

$\mathrm{PEX}+$ cataract $=$ pseudoexfoliative syndrome and cataract $; \mathrm{POAG}+$ cataract $=$ primary open-angle glaucoma and cataract PEX glaucoma+cataract $=$ pseudoexfoliative glaucoma and cataract

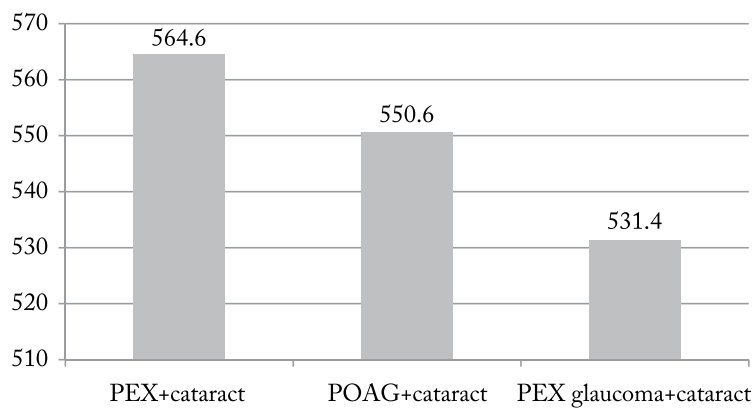

Fig. 2. Comparison of central corneal thickness mean values according to study groups.

$\mathrm{PEX}+$ cataract $=$ pseudoexfoliative syndrome and cataract POAG + cataract $=$ primary open - angle glaucoma and cataract; PEX glau coma + cataract $=$ pseudoexfoliative glaucoma and cataract

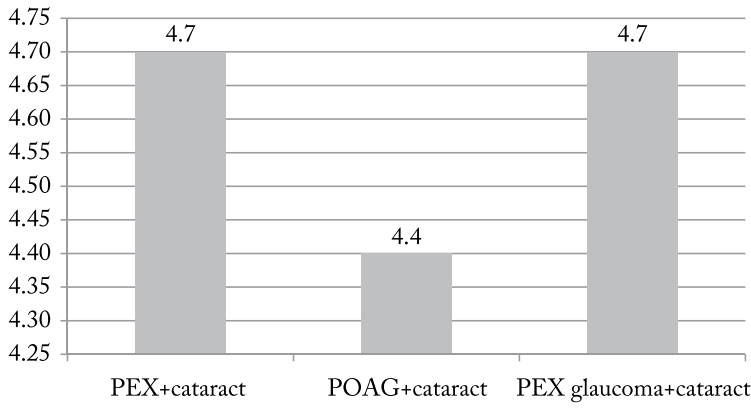

Fig. 3. Comparison of lens thickness mean values according to study groups.

PEX + cataract $=$ pseudoexfoliative syndrome and cataract; POAG + cataract $=$ primary open-angle glaucoma and cataract; PEX glau coma + cataract $=$ pseudoexfoliative glaucoma and cataract

cataract) revealed statistically significant differences in $\operatorname{CCT}\left(\mathrm{F}_{2 / 99}=7.066 ; \mathrm{p}=0.001\right)$ and LT $\left(\mathrm{F}_{2 / 96}=5.133\right.$; $\mathrm{p}=0.008$ ) (Table 1 ). The eyes diagnosed with PEX syn- 
Table 1. Comparative analysis of biometric factors according to study groups

\begin{tabular}{|l|l|l|l|l|l|l|l|l|l|l|l|l|}
\hline & \multicolumn{3}{l|}{ PEX syndrome + cataract } & \multicolumn{3}{l|}{ POAG + cataract } & \multicolumn{2}{l|}{ PEX glaucoma + cataract } & \multirow{2}{*}{ F; df; p } \\
\hline & $\mathrm{n}$ & $\mathrm{M}$ & $\mathrm{SD}$ & $\mathrm{n}$ & $\mathrm{M}$ & $\mathrm{SD}$ & $\mathrm{n}$ & $\mathrm{M}$ & SD & \\
\hline AL & 27 & 22.8 & 0.771 & 35 & 22.9 & 1.092 & 30 & 23.0 & 0.819 & $0.599 ; 2 / 89 ; 0.703$ \\
CCT & 29 & 564.6 & 39.547 & 36 & 550.6 & 29.243 & 37 & 531.4 & 38.951 & $7.066 ; 2 / 990.001^{* *}$ \\
ACD & 29 & 2.3 & 0.397 & 36 & 2.5 & 0.395 & 36 & 2.4 & 0.551 & $1.258 ; 2 / 98 ; 0.289$ \\
LT & 27 & 4.7 & 0.444 & 36 & 4.4 & 0.417 & 36 & 4.7 & 0.435 & $5.133 ; 2 / 96 ; 0.008^{* *}$ \\
K2 & 29 & 43 & 1.299 & 36 & 43.5 & 1.742 & 37 & 43.2 & 1.143 & $0.894 ; 2 / 99 ; 0.412$ \\
K1 & 29 & 43.9 & 1.330 & 36 & 44.2 & 1.843 & 37 & 44.2 & 1.132 & $0.638 ; 2 / 99 ; 0.530$ \\
AST & 29 & 0.9 & 0.465 & 36 & 2.1 & 7.716 & 37 & 1.0 & 0.591 & $3.519 ; 2 ; 0.172^{\#}$ \\
WTW & 29 & 12.0 & 0.495 & 36 & 11.9 & 0.634 & 36 & 11.8 & 0.702 & $1.369 ; 2 / 98 ; 0.259$ \\
PD & 29 & 5.2 & 1.194 & 35 & 5.1 & 1.329 & 32 & 4.6 & 0.927 & $2.732 ; 2 / 93 ; 0.07$ \\
\hline
\end{tabular}

$\mathrm{PEX}$ syndrome = pseudoexfoliative syndrome; $\mathrm{POAG}=$ primary open-angle glaucoma; $\mathrm{PEX}$ glaucoma = pseudoexfoliative glaucoma; $\mathrm{AL}$ = axial length; $\mathrm{CCT}=$ central corneal thickness; $\mathrm{ACD}=$ anterior chamber depth; $\mathrm{LT}=$ lens thickness; $\mathrm{K} 1=$ keratometry of the steepest meridian; K2 = keratometry of the flattest meridian; AST = astigmatism; WTW = horizontal corneal diameter (white-to-white); PD = pupillary diameter; $\mathrm{n}=$ number of patients; $\mathrm{M}=$ arithmetic mean; $\mathrm{SD}=$ standard deviation; $\mathrm{F}=$ analysis of variance; $\mathrm{df}=\mathrm{degrees}$ of freedom; $\mathrm{p}=$ probability of error; ${ }^{* *} \mathrm{p}<0.01 ;$ Kruskal-Wallis test

drome/cataract had a statistically significantly greater CCT than those diagnosed with PEX glaucoma/cataract $(564.6 \pm 39.54 \mu \mathrm{m}$ vs. $531.4 \pm 8.95 \mu \mathrm{m}$; Scheffe test, $\mathrm{p}=0.002)$. Other CCT differences did not reach statistical significance (POAG/cataract vs. PEX glaucoma/ cataract: Scheffe test, $\mathrm{p}=0.081$; and PEX syndrome/ cataract vs. POAG/cataract: Scheffe test, $\mathrm{p}=0.302$ ) (Fig. 2). Analysis of the results showed the eyes diagnosed with PEX syndrome/cataract and those with PEX glaucoma/cataract to have a statistically significantly thicker lens than the eyes diagnosed with POAG/cataract $(4.7 \pm 0.444 \mathrm{~mm}$ and $4.7 \pm 0.417 \mathrm{~mm}$, respectively vs. $4.4 \pm 0.417 \mathrm{~mm}$; Scheffe test, $\mathrm{p}=0.041$ and $\mathrm{p}=0.018$, respectively). Lens thickness did not differ between the eyes diagnosed with PEX syndrome/ cataract and those with PEX glaucoma/cataract (Scheffe test, $\mathrm{p}=0.995$ ) (Fig. 3).

\section{Discussion}

Assessment of biometric status of the eye has a major role in cataract, glaucoma and refractive surgery. The use of new generation biometric formulas requires thorough analysis of biometric measures in the eye in order to achieve the best possible postoperative results. Furthermore, previous studies have documented the relationship of aberrations in particular biometric factors with a higher risk of intra- and postoperative complications in cataract surgery. Knowing the bio- metric status of the eye in detail is a precondition for successful operative course prediction, adjustment and selection of operative techniques and intraocular artificial lens implants, and for postoperative result assessment. PEX syndrome is a disorder of the elderly, frequently associated with development of cataract and glaucoma.

Our study included 102 eyes in 72 patients (44 female and 28 male), clearly showing female predominance $(60.6 \%)$, which could be explained by demographic characteristics of the population and greater proportion of women in the elderly population in general. The prevalence of PEX syndrome is known to be higher in women, whereas PEX glaucoma occurs more frequently in $\operatorname{men}^{5,6}$. In the present study, the proportion of women was greater in the PEX syndrome/cataract and POAG/cataract groups (63\%) as compared with the PEX glaucoma/cataract group (55\%). In the latter, the proportion of men was higher as compared with the other two groups; however, the difference was not statistically significant $\left(\chi^{2}=0.486 ; s s=2 ; p=0.784\right)$.

The mean patient age was significantly higher in the PEX syndrome/cataract and PEX glaucoma/cataract groups $(79.61 \pm 6.50$ and $79.41 \pm 5.27$ years, respectively) as compared with the POAG/cataract group (70.81 \pm 7.80 years) (Scheffe test, $\mathrm{p}<0.001)$. The results obtained are consistent with literature data on the risk of PEX syndrome and PEX glaucoma to rise with age. The incidence of PEX syndrome is on an increase with 
population aging worldwide ${ }^{5,6}$ PEX syndrome is a generalized disorder that involves almost all segments of the eye, mostly bilaterally. It develops gradually and the lesions are considered to occur much earlier than becoming clinically visible on the lens capsule and $\mathrm{pu}^{-}$ pillary opening. Therefore, it is of utmost importance to support development of diagnostic methods to directly or indirectly point to lesions in the earlier stage of the disease. Previous studies employing various biometric methods have reported contradictory results on biometric characteristics of the eye with PEX syndrome and PEX glaucoma.

In our sample of eyes divided into three groups, we recorded statistically significant CCT differences between the PEX syndrome/cataract and PEX glauco$\mathrm{ma} /$ cataract groups $(564.6 \pm 39.54 \mu \mathrm{m}$ vs. $531.4 \pm 38.95$ $\mu \mathrm{m}$; Scheffe test, $\mathrm{p}=0.002$ ). The group of eyes diagnosed with PEX glaucoma and cataract had a significantly thinner cornea as compared with the other two groups. Using ultrasound (US) pachymetry and comparison of samples of normotensive and PEX syndrome eyes with and without glaucoma, Puska et al. report on significantly higher CCT values in patients with PEX syndrome ${ }^{16}$. Results consistent to ours have been published by Bechmann et al:; using optical coherence tomography, they point to lower CCT values measured in patients with PEX glaucoma ${ }^{17}$. In contrast, Arnarsson et al. (Reykjavik Eye Study) found no association between the presence of PEX syndrome and aberrations in CCT, ACD and LT values ${ }^{5}$. Using the Pentacam Scheimpllug imaging system, Doganay et al. found no CCT and PD differences among patients with PEX glaucoma, those with PEX syndrome and control group ${ }^{18,19}$. Rufer et al. recorded no statistically significant differences, whereas Inoue et al. report on thinner cornea in patients with PEX syndrome with or without glaucoma as compared with control group, but found no statistically significant difference between the PEX syndrome and PEX glaucoma groups. They report on the association between reduced corneal endothelial cell count and decreased CCT value in patients with PEX glaucoma ${ }^{20,21}$. The onset of PEX syndrome is known to be accompanied by corneal lesions that manifest as alterations of the corneal epithelial, stromal and endothelial cells, as well as of Descemet's membrane of the cornea. These alterations include changes in the cell number and morphology that occur due to metabolic changes, produc- tion and accumulation of PEX material, and changes in aqueous humor, resulting in cell disintegration, migration, uncontrolled proliferation and eventually apoptosis, with aggravation of these alterations in the presence of elevated intraocular pressure ${ }^{20-23}$. Corneal lesions in PEX syndrome can cause corneal decompensation and are a major factor in the assessment of postoperative results.

In the present study, patients diagnosed with PEX syndrome/cataract and those with PEX glaucoma/ cataract had a statistically significantly thicker lens than patients diagnosed with POAG/cataract $(4.7 \pm$ $0.444 \mathrm{~mm}$ and $4.7 \pm 0.417 \mathrm{~mm}$ vs. $4.4 \pm 0.417 \mathrm{~mm}$, respectively; Scheffe test, $\mathrm{p}=0.041$ and $\mathrm{p}=0.018$, respectively). Lens thickness did not differ between patients with PEX syndrome/cataract and those with PEX glaucoma/cataract (Scheffe test, $\mathrm{p}=0.995$ ). The lens grows with age and the mentioned differences can in part be explained by advanced age of patients in the groups with PEX syndrome with and without glaucoma; however, lens surface in PEX syndrome is known to manifest structural central and peripheral alterations. Formation of a precapsular layer made of profibrillar material, followed by formation of a layer consisting of organized PEX material and pigment has been identified by electron microscopy and histochemistry. Localized accumulation of PEX material and degenerative changes resulting in disintegration at capsular holder occur in the area of zonule insertion. Tension and contact between the lens capsule and zonule decrease with weakness of the zonular apparatus, rendering the lens thicker and ever more mobile. Using US biomicroscopy, Unsal et al. detected thicker lens and degenerative changes at the zonule capsular holder in the eye with PEX syndrome, unlike the other eye without PEX syndrome ${ }^{23}$. Some literature reports speculate that weakness of the zonular apparatus and increased lens thickness may cause lens antepositioning and decreased depth of the anterior chamber. These changes pose a risk of chamber angle closure and onset of glaucoma in PEX syndrome, as well as of intra- and postoperative complications in cataract surgery ${ }^{10-13}$. Increased lens thickness leads to closer iridolental contact and potential formation of adhesions, which will also result in increased resistance to aqueous humor drainage and development of glaucoma. These alterations, as well as epithelial and stromal changes of the ciliary muscle and iris are additional factors contribut- 
ing to the inability of adequate mydriasis and reduced pupillometry in cataract surgery, thus increasing the risk of intra- and postoperative complications. Employing OLCR, Bosnar et al. found statistically significantly lower ACD and PD values and a statistically significantly thicker lens in the sample of eyes with PEX syndrome and cataract as compared with the eyes with cataract ${ }^{15}$. Naumann confirmed lower $\mathrm{PD}$ values in the eyes with PEX syndrome ${ }^{24}$. In our study, comparative analysis of study groups yielded no statistically significant differences in the measured PD and $A C D$ values, although the mean $A C D$ value was below $2.5 \mathrm{~mm}$ in the groups with PEX syndrome/ cataract and PEX glaucoma/cataract $(2.3 \pm 0.397 \mathrm{~mm}$ and $2.4 \pm 0.551 \mathrm{~mm}$, respectively), which could in part be explained by greater lens thickness and inadequate response to medicamentous mydriasis due to the iris and zonular apparatus alterations described above.

Küchle et al. report that ACD $<2.5 \mathrm{~mm}$ correlates with a fourfold greater risk of intraoperative complications ${ }^{12}$. Pupillometry was lowest in the PEX glauco$\mathrm{ma} /$ cataract group $(4.6 \pm 0.92 \mathrm{~mm})$ as compared with POAG/cataract group $(5.1 \pm 1.32 \mathrm{~mm})$ and PEX syndrome/cataract group $(5.2 \pm 1.194 \mathrm{~mm})$, however, without statistical significance $(F=2.732 ; s s=2 / 93 ; p=0.07)$. Smaller pupillary diameter points to possible association with structural changes of iris tissue, presence of iridolental adhesions, glaucoma, and greater likelihood of intraoperative complications. On analysis of biometric status according to age, a statistically significant correlation was recorded for LT $(\mathrm{r}=0.472 ; \mathrm{p}=0.027)$ and WTW ( $r=0.512 ; \mathrm{p}=0.015)$ in the PEX glaucoma/ cataract group. Older patients had thicker lens and smaller corneal diameter. WTW is an indirect indicator of iris diameter, lens capsule diameter, ciliary sulcus and anterior chamber depth, and in this case an important factor in the assessment of intraocular lens choice and positioning.

\section{Conclusion}

Using OLCR, we found differences in the values of biometric factors among the study groups, and a statistically significantly thinner cornea and thicker lens in the group of glaucomatous patients with PEX syndrome. Our results confirmed OLCR as a biometric method in preoperative diagnosis to help in detecting glaucomatous patients with PEX syndrome. The pur- pose of the study was to instigate scientific ideas in search for novel methods to diagnose specificities of ocular biometric factors in glaucomatous patients with PEX syndrome.

\section{References}

1. Kanski JJ. Glaucoma. In: Kanski JJ. Clinical Ophthalmology. Philadelphia: Butterworth Heinemann Elsevier; 2007:371-440.

2. Schlötzer-Schrehardt U. New pathogenetic insights into pseudoexfoliation syndrome/glaucoma. Therapeutically relevant? Ophthalmologe. 2012;109:944-51. doi: 10.1007/s00347-0122531-1

3. Sherwood M. Glaucoma. In: Yanoff M, Duker JS (eds.). Ophthalmology. St. Louis: Mosby Elsevier; 2004:1413-610.

4. Schlötzer-Schrehardt U, Naumann GO. Ocular and systemic pseudoexfoliation syndrome. Am J Ophthalmol. 2006;141: 921-37. doi: 10.1016/j.ajo.2006.01.047

5. Arnarsson A, Damji KF, Sverrisson T, Sasaki H, Jonasson F. Pseudoexfoliation in the Reykjavik Eye Study: prevalence and related ophthalmological variables. Acta Ophthalmol Scand. 2007;85:822-7. doi: 10.1111/j.1600-0420.2007.01051.x

6. Viso E, Rodríguez-Ares MT, Gude F. Prevalence of pseudoexfoliation syndrome among adult Spanish in the Salnés Eye Study. Ophthalmic Epidemiol. 2010;17:118-24. doi: $10.3109 / 09286581003624970$

7. Ritch R, Schlötzer-Schrehardt U. Exfoliation syndrome. Surv Ophthalmol. 2001;45:265-315. doi: 10.1016/S0039-6257(00)00196-X

8. Schlötzer-Schrehardt U, Pasutto F, Sommer P, Hornstra I, Kruse FE, Naumann GO, Reis A, Zenkel M. Genotype-correlated expression of lysyl oxidase-like 1 in ocular tissues of patients with pseudoexfoliation syndrome/glaucoma and normal patients. Am J Pathol. 2008;173:1724-35. doi: 10.2353/ajpath.2008.080535

9. Schlötzer-Schrehardt U. Molecular pathology of pseudoexfoliation syndrome/glaucoma: new insights from LOXL1 gene associations. Exp Eye Res. 2009;88:776-85. doi: 10.1016/j. exer.2008.08.012

10. Ritch R, Schlötzer-Schrehardt U, Konstas AG. Why is glaucoma associated with exfoliation syndrome? Prog Retin Eye Res. 2003;22:253-75. doi: 10.1016/S1350-9462(02)00014-9

11. Schlötzer-Schrehardt U, Naumann GO. A histopathologic study of zonular instability in pseudoexfoliation syndrome. Am J Ophthalmol. 1994;118:730-43. doi: 10.1016/S0002-9394(14)72552-8

12. Küchle M, Viestenz A, Martus P, Händel A, Jünemann A, Naumann GO. Anterior chamber depth and complications during cataract surgery in eyes with pseudoexfoliation syndrome. Am J Ophthalmol. 2000;129:281-5. doi: 10.1016/ S0002-9394(99)00365-7

13. Drolsum L, Ringvold A, Nicolaissen B. Cataract and glaucoma surgery in pseudoexfoliation syndrome: a review. Acta Ophthalmol Scand. 2007;85:810-21. doi: 10.1111/j.1600-0420.2007.00903.x 
14. Aström S, Stenlund H, Lindén C. Incidence and prevalence of pseudoexfoliation and open-angle glaucoma in northern Sweden: II. Results after 21 years of follow-up. Acta Ophthalmol Scand.2007;85:832-7. doi: 10.1111/j.1600-0420.2007.00980.x

15. Bosnar D, Kuzmanović Elabjer B, Bušić M, Bjeloš Rončević M, Miletić D, Barać J. Optical low-coherence reflectometry enables preoperative detection of zonular weakness in pseudoexfoliation syndrome. Graefes Arch Clin Exp Ophthalmol. 2012;250:87-93. doi: 10.1007/s00417-011-1771-0

16. Puska P, Vasara K, Harju M, Setala K. Corneal thickness and corneal endothelium in normotensive subjects with unilateral exfoliation syndrome. Graefes Arch Clin Exp Ophthalmol. 2000;238:659-63. doi: 10.1007/s004170000159

17. Bechmann M, Thiel MJ, Roesen B, Ullrich S,Ulbig MW, Ludwig K. Central corneal thickness determined with optical coherence tomography in various types of glaucoma. Br J Ophthalmol. 2000;84:1233-7. doi: 10.1136/bjo.84.11.1233

18. Hepsen IF, Yağci R, Keskin U. Corneal curvature and central corneal thickness, in eyes with pseudoexfoliation syndrome. Can J Ophthalmol. 2007;42:677-80. doi: 10.3129/i07-145

19. Doganay S, Tasar A, Cankaya C, Firat PG, Yologlu S. Evaluation of Pentacam-Schleimpflug imaging of anterior segment parameters in patients with pseudoexfoliation syndrome and pseudoexfoliative glaucoma. Clin Exp Optom. 2012;95: 218-22. doi: 10.1111/j.1444-0938.2011.00691.x

20. Rufer F, Westphal S, Erb C. Comparison of central and peripheral corneal thicknesses between normal subjects and patients with primary open angle glaucoma, normal tension glaucoma and pseudoexfoliation glaucoma. Klin Monatbl Augenheilkd. 2007;224:636-40. doi: 10.1055/s-2007-963337

21. Inoue K, Okugawa K, Oshika T, Amano S. Morphological study of corneal endothelium and corneal thickness in pseudoexfoliation syndrome. Jpn J Ophthalmol. 2003;47:235-9. doi: 10.1016/S0021-5155(03)00022-4

22. Naumann GO, Schlötzer-Schrehardt U. Keratopathy in pseudoexfoliation syndrome as a cause of corneal endothelial decompensation: a clinicopathologic study. Ophthalmology. 2000;107:1111-24. doi: 10.1016/S0161-6420(00)00087-7

23. Unsal E, Eltutar K, Muttuoglu I, Akcetin TA, Acara Y. Ultrasound biomicroscopy in patients with unilateral pseudoexfoliation. Int J Ophthalmol. 2015;8:754-8. doi: 10.3980/j.issn.22223959.2015.04.20

24. Naumann GO. Exfoliation syndrome as a risk factor for vitreous loss in extracapsular cataract surgery (preliminary report). Erlanger Augenblätter Group. Acta Ophthalmol Suppl. 1988; 184:129-31. doi: 10.1111/j.1755-3768.1988.tb02645.x

25. Buckhurst PJ, Wolffsohn JS, Shah S, Naroo SA, Davies LN, Berrow EJ. A new optical low coherence reflectometry device for ocular biometry in cataract patients. Br J Ophthalmol. 2009; 93:949-53. doi: 10.1136/bjo.2008.156554

26. Cruysberg LP, Doors M, Verbakel F, Berendschot TT, De Brabander J, Nuijts RM. Evaluation of the Lenstar LS 900 noncontact biometer. Br J Ophthalmol. 2010;94:106-10. doi: 10.1136/bjo.2009.161729

Sažetak

\title{
SPECIFIČNOSTI BIOMETRIJSKIH ČIMBENIKA OKA U GLAUKOMSKIH BOLESNIKA S PSEUDOEKSFOLIJATIVNIM SINDROMOM MJERENIH OPTIČKOM NISKOKOHERENTNOM REFLEKTOMETRIJOM
}

\author{
Ž. Janjetović, M. Bušić, D. Bosnar, J. Barać i I. Genda
}

Cilj je bio optičkom niskokoherentnom reflektometrijom utvrditi odstupanja i razlike biometrijskih čimbenika između skupina ispitivanih uzoraka očiju s kataraktom i pseudoeksfolijativnim sindromom, kataraktom i pseudoeksfolijativnim glaukomom i kataraktom i primarnim glaukomom otvorenog kuta te odrediti biometrijske čimbenike oka specifične za skupinu glaukomskih bolesnika s pseudoeksfolijativnim sindromom. U retrospektivnu studiju bilo je uključeno 72 ispitanika, a uzorak su činila 102 oka podijeljena u tri skupine prema dijagnozi: 29 očiju s pseudoeksfolijativnim sindromom i kataraktom, 36 očiju s primarnim glaukomom otvorenog kuta i kataraktom, 37 očiju s pseudoeksfolijativnim glaukomom i kataraktom. Detaljnom analizom medicinske dokumentacije ispitanika predviđenih za operaciju katarakte u Klinici za očne bolesti Kliničke bolnice Sveti Duh u Zagrebu prikupljeni su i analizirani podaci biometrijskih mjerenja (centralna debljina rožnice, promjer zjenice, dubina prednje sobice, debljina leće, aksijalna duljina, debljina rožnice, astigmatizam i horizontalni promjer rožnice izmjereni primjenom optičke niskokoherentne reflektometrije na uređaju Lenstar LS $90{ }^{\circledR}$, Haag Streit International). Usporednom analizom skupina zabilježene su statistički značajne razlike za centralnu debljinu rožnice (F2/99=7,066; $\mathrm{p}=0,001)$ i debljinu leće $(\mathrm{F} 2 / 96=5,133 ; \mathrm{p}=0,008)$. Skupina očiju s dijagnozom pseudoeksfolijativnog glaukoma i katarakte imala je značajno tanju rožnicu u odnosu na ostale dvije skupine očiju i značajno deblju leću od skupine s primarnim glaukomom otvorenog kuta i kataraktom. U zaključku, primjenom optičke niskokoherentne reflektometrije utvrđene su razlike u biometrijskim čimbenicima promatranih skupina i statistički značajno tanja rožnica te zadebljana leća u skupini glaukomskih bolesnika s pseudoeksfolijativnim sindromom.

Ključne riječi: Eksfolijacijski sindrom; Optička niskokoherentna refektometrija; Glaukom otvorenog kuta; Katarakta 